\title{
MOBILE AUGMENTED REALITY APPLICATION FOR PRIMARY SCHOOL EDUCATION
}

\author{
Normala Rahim, Wan Rizhan, Maizan Mat Amin, Wan Malini Wan Isa, \\ Ismahafezi Ismail, Nur SaadahMohd Shapri, Rafhanah Ramlan \\ Faculty of Informatics \& Computing, Universiti Sultan Zainal Abidin, \\ Besut Campus 22200 Besut, Terengganu, Malaysia
}

\begin{abstract}
Mobile-based Augmented Reality (AR) has grown rapidly in various sectors including an education field. This technology has supported in facilitating users to perform daily tasks such as tools in teaching and learning. However, in teaching and learning activities still practise a traditional method by using books that have caused students feel bored and cannot focus in the activities. Therefore, with the advent of 'BelajarBacaanSolat' using Augmented Reality (AR-BBS) application these students can utilize this to improve students' level of understanding as well as attract them to stay focus in the learning. The objective of this project was to help the primary school students to study an Islamic subject namely Kelas al-Quran dan Fardu Ain (KAFA). In addition, this project can also benefit to KAFA teachers in teaching student more effectively. This research focus on the topic of "BacaanSolat" in prayer. The framework proposed in this research contains three items including entity, platform and content. In conclusion, this project can help student especially KAFA student learn more efficiently. It is believed that this application can help the students to improve their skills and attract to learn KAFA effectively.
\end{abstract}

\section{KEYWORDS}

Augmented Reality, Mobile Application, Primary school education.

\section{INTRODUCTION}

Today, one of the most popular multimedia technologies was an Augmented Reality (AR) that can be used in the field of education. The augmented reality features that can produce a real time 3D objects can help students to better understand the content of a subject [1], [2].

The advent of augmented reality (AR) technology based on mobile phones is now rapidly growing in the market. It has started to explore in more depth which produces new functions that makes the study more interesting. This technology provides users with an intuitive interaction, navigation and manipulation. Users are able to travel in an immersive virtual environment through the manipulation of virtual objects in real time [3], [4].

Augmented Reality (AR) has been an emerging technology in these recent years. AR (Augmented Reality) defined as immersion of virtual environment to the real environment which it enriches the vision, audition or even taste, touch and smell [5]. The significant timeline of AR technology begun from a cinematographer, Morton Heiling which he thought cinema should enable interaction between a human and the environment covering all the senses [5]. The first AR Head Mounted Display was developed by Sutherland [6] while the ability to interact with virtual objects was first introduced by Myron Krueger [7]. 
The International Journal of Multimedia \& Its Applications (IJMA) Vol.13, No. 6, December 2021

Nowadays, smartphones have the core features to develop an AR application such as camera, touch screen, Inertia Measurement Unit (IMU), internet access and so forth [5]. The advancement of smartphone technologies which enable real time image processing camera and powerful performance from built-in Central Processing Unit (CPU) and Graphics Processing Unit (GPU) made basic AR application development easier without external supporting device.

This new technology, called augmented reality is a combination of what's real and what's computer-generated by enhancing what we see, hear and feel. Its combines real and virtual images both can be seen at the same time. When compared to other reality technologies, augmented reality lies in the middle of the mixed reality spectrum between the real world and the virtual world.

Furthermore, AR is changing the way we view the world or at least the way its users see the world [3]. Additionally, augmented reality adds graphics, sounds and haptic feedback to the natural world as it exists. This AR-BBS developed with a flashcard using AR Technology created for students of Islamic class in primary school. It is focused on prayers in Salah for students to learn and improve prayers with interactive medium. Users need to scan the flashcard of the prayer in Salah using their mobile phones. Then, the model and the prayers animation in Salah will appear on the phone automatically with sound of prayers in Salah correctly.

In the beginning of this research, an interview was conducted as an initial study to identify an issue in teaching and learning for the KAFA subject. Currently, the teachers still use book as a material for teaching and learning activities. As we already know, the books only contain texts and 2D image which led students feel bored, hard to memorised and less interesting. However, in the early exposure it is important for students to use an effective learning as an aid in studies to increase their interest to memorize prayers in Salah.

Overall, it can be concluded that by utilizing AR technology can enhance students understanding and creates a more engaging and interactive learning environment and sees virtual objects in the real world as well as various multimedia elements such as animation, image, audio, text and video. The next sections are about related works in Section 2, methodology in Section 3, results and discussion in Section 4 and lastly conclusion in Section 5.

\section{RELATED WORKS}

This chapter discusses about previous work regarding AR Technology. This section discusses indepth into prior research on AR platform for E-Learning application. In this literature review, a research has been made to understand and get some overview about existing research and related technology.

\subsection{Augmented Reality Techniques}

Generally, there are two types techniques of AR applications that have been reported in [8] AR based marker (marker-based AR) and AR without marker less (marker less AR). According to [9], the marker is an image of black and white in terms of rectangles and during the detection process this marker will be used and the computer will detect the position and oriented by the marker to create a virtual object in the form of an object $3 \mathrm{D}$ at point $(0,0,0)$ and three angles $(X$, $\mathrm{Y}, \mathrm{Z})$.

In addition, AR-based markers require a certain marker or label to register a 3D virtual object position that will be displayed in a real-world environment [10]. Usually, marker was design in a 
rectangular card or paper which over the card has a certain pattern or line with different id and code. Thus, a laptop camera or smartphone will detect the position of the AR marker scan on the flash card and then the virtual element will be generated by the AR software. Then, the 3D virtual object will appear on the screen in a more interactive.

In contrast to the AR marker less method, using location or location data generated by mobile devices, global positioning systems or any part of the real environment to determine location and targeting, then generating and displaying information virtually [9]. Additionally, AR without markers also has various techniques including face detection, 3D object detection and motion detection. The following figure 2.1 and 2.2 illustrate the example of a product using different techniques.

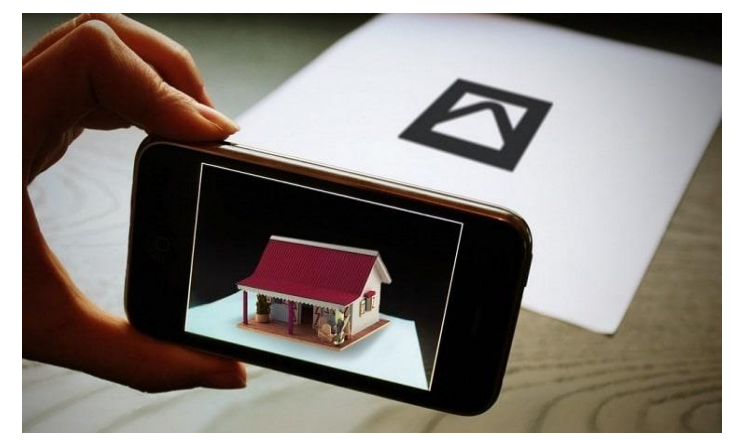

Figure 2.1 Marker-based AR

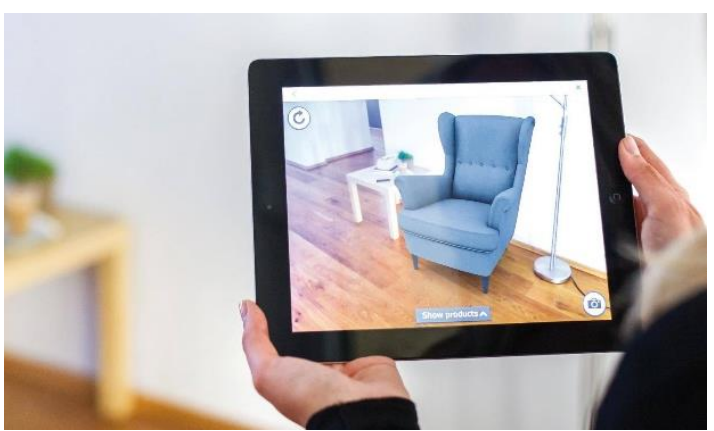

Figure 2.2 Marker less AR

\subsection{Previous Research using Marker-based AR}

According to [11], the purpose of this study was testing the effectiveness of primary student mastery level of "RukunQauli" during their "solat". The respondents selected for this particular study were ten female students from the same primary school. This study is to identify how effective the learning technique by using coloured card in mastering the reading of "rukunqauli" in prayers. Beside that, it is also to identify how far the acceptance and comprehension towards the reading of "rukunqauli" in prayers.

Furthermore, the research also aims to measure pupils understanding of the importance "rukunqauli" during their "solat". Based on the findings, we can assume that $90 \%$ of the students have attained at least mastery level of understanding the importance of "rukunqauli" during their prayers. The study also highlights the importance of reinforcement and remedial to ensure there is continuity in learning. 
The International Journal of Multimedia \& Its Applications (IJMA) Vol.13, No. 6, December 2021

E-Solat courseware was developed by [12] that can guide user especially kids (6-10 years) old on how doing a right step of a Salah. This courseware divides into two main courses which is learning Salah and remembering short surah. Under Salah, there are five options and kids can choose which Salah he or she wants to learn. The options are 'SolatSubuh, SolatZohor, SolatAsar, SolatMagrib and SolatIsya'. The animation will teach kids on how to Salah.

According to [13], it is provided that one of the programs available is Muslim Prayer Guide applications that can be downloaded for free via mobile devices such as smartphones and tablets. Affective factors, such as embarrassment towards instructors and peers can disrupt learning. One of the technologies that have the potential to address this issue is mobile learning. As such, we develop a mobile application in attempting to solve the issue of learner embarrassment in learning about praying.

Muslim Prayer Guide application is built is intended as a guide to the Muslim citizens of all ages to perform prayers in the prayer in Islam. The content of this application is the rule of prayer, how to perform ablution, the things that invalidate the prayer, the reading of the five daily prayers. This study was conducted to identify the factors that contributed to the Android Muslim Prayer Guide. The study was carried out using quantitative technique by submitting a questionnaire instrument to the 62 respondents who use this application.

The analysis was done by using the Rasch measurement model and to measure the effectiveness factors of these applications. The results showed that the use of this application Muslim prayers assist learners in terms of the level of knowledge and methods of teaching and learning guides prayers. This application also helps adult learners who want to learn prayers. The Muslim Prayer Guide also assist them in prepare before meeting with a teacher to learn the prayers and to equip themselves as a Muslim to perform the second pillar of Islam.

This application provides a complete guide on how to do a daily and sunat prayer. This application let you learn a prayer of a sunat and a daily prayer through interactive content. It is accessible and easy to use. Furthermore, the screen display in HD quality that can zoom in and zoom out without affecting the display quality (blur).

A proper prayer is important to ensure that our prayers are accepted by Allah Almighty. Therefore, this app is developed as a reference to all women in performing prayers. This application provides proper procedure and prayers in the correct manner. The content is detailed like book. This application was released on October 2, 2018 and user can get on play store for free.

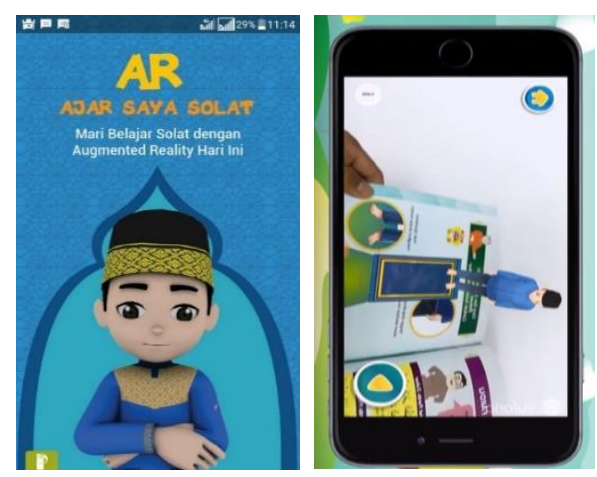

Figure 3. An Application of Ajar Saya Solat 
The International Journal of Multimedia \& Its Applications (IJMA) Vol.13, No. 6, December 2021

According to [14] it is provided on how to perform prayers easily. This application is easy to be use by only pointing the camera gadget towards the flashcards. After that, a 3D animation will appear. This application helps to memorize the recitation in prayers. This application also can form the children by using the gadget with beneficial content.

Table 2.1: Comparison of the Existing Products.

\begin{tabular}{|l|l|r|r|r|r|c|}
\hline NO. & \multicolumn{1}{|c|}{ TITTLE } & T & I & V & AU & AN \\
\hline 1. & $\begin{array}{l}\text { Flashcard: Bacaan Rukun } \\
\text { Qauli Dalam Solat }\end{array}$ & $\checkmark$ & $\checkmark$ & - & - & - \\
\hline 2. & $\begin{array}{l}\text { Mobile Apps: E-Solat } \\
\text { Mobile Apps: The User Guide } \\
\text { Muslim Prayer }\end{array}$ & $\checkmark$ & $\checkmark$ & - & - & - \\
\hline 4. & $\begin{array}{l}\text { Mobile Apps: Panduan } \\
\text { Lengkap Solat }\end{array}$ & $\checkmark$ & - & - & $\checkmark$ & - \\
\hline 5. & $\begin{array}{l}\text { Mobile Apps: Panduan Solat } \\
\text { Sempurna Wanita }\end{array}$ & $\checkmark$ & $\checkmark$ & - & - & - \\
\hline 6. & $\begin{array}{l}\text { Mobile Apps (AR): Ajar } \\
\text { Saya Solat' }\end{array}$ & - & $\checkmark$ & - & $\checkmark$ & $\checkmark$ \\
\hline
\end{tabular}

Based on the table 2.1, the conclusion that can be concluded from the hand-on product is all of it using text and image, but it is too much text in one page and less attractive. The images only appear in 2D and no animation element. In terms of audio usage, only one product used audio and it only focused on audio no text and image. Lastly, the product to be built is based on AR technology that have image in 3D animation and text with sound and have two activities for student to improve after learning process. The learning process will be more fun and can give a new experience to the student. Based on the related works done previously, Mobile-based AR applications have been contributing to education especially in the education field. Therefore, it is very appropriate to apply the mobile-based AR in learning KAFA subject by a primary school student.

\section{Methodology}

This project has been developed on a Windows operated hardware and an Android Phone simulator. The major software used is Vuforia SDK, Unity 3D and Autodesk Maya. Figure 3.1 shows the overview of AR-BBS application which involves entities such as students and teacher. The students can used this application for learning experience whereas teachers can used this for teaching in the class.

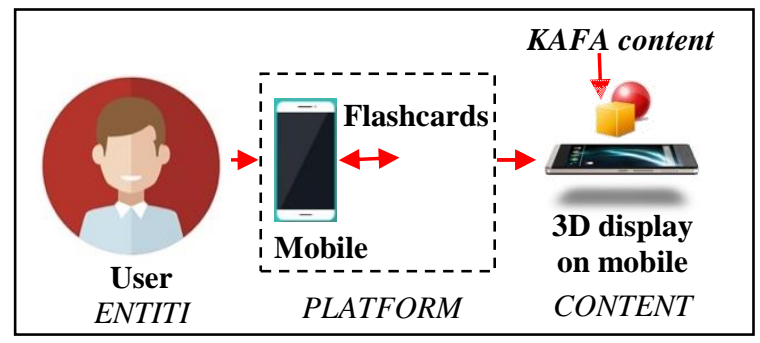

Figure 3.1: Overview of AR-BBS Application 
The International Journal of Multimedia \& Its Applications (IJMA) Vol.13, No. 6, December 2021

For the learning experience to the primary school students and teachers towards the education 4.0, we develop a mobile apps using AR technology which requires users to scan flashcards that contain "BacaanSolat" using a mobile. The entire system framework can be depicted as in Figure 3.2. The users needed to used device to search the marker in flashcard, for the best results, you should aim for targets with 4 or 5 starts. The adobe illustrator used to create flashcard prayer in Salah and to create interface of the AR-BBS application. Autodesk Maya software used to model the character in 3D and make the 3D model movement and look realistic. The 3D Unity used to create the Virtual Reality application and overall project and modelling 3D objects. The Vuforia use to create augmented reality. The Vuforia detects and tracks the features that are naturally found in the image itself by comparing these natural features against a known target resource database. Once the Image Target is detected, Vuforia Engine will track the image as long as it is at least partially in the camera's field of view. Lastly, after scanning the marker, 3D image will display to user. From this, the user will learn a new experience in learning process.

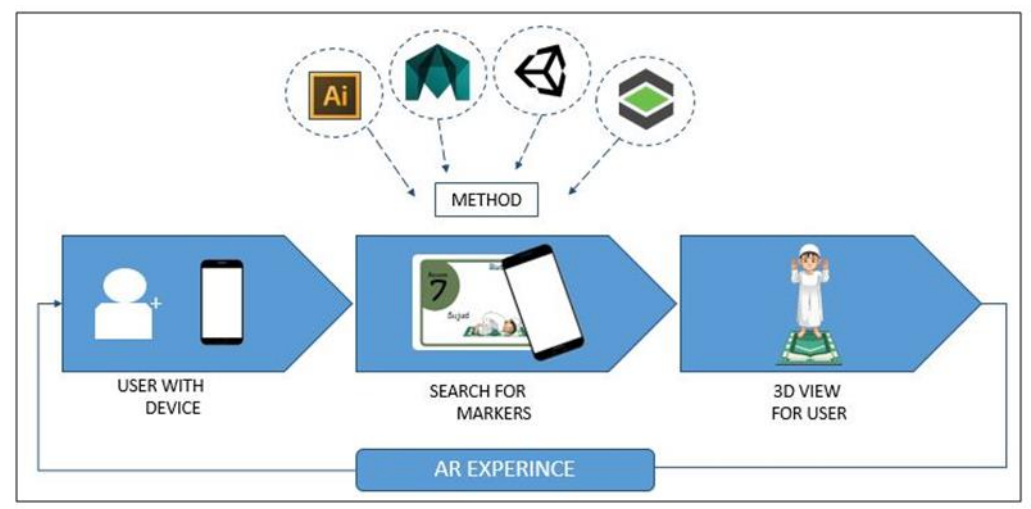

Figure 3.2: Application Framework

\section{RESUlTS \& DisCUSSION}

In the cutover stages, the hardware and software content were mapping and tested either it is suitable and compatible with the project requirement. The final phase in RAD approach is cutover phases or known as implementation stages. This phase only can be done after the testing has been completed therefore the software can be installed in a "live" environment and launched. The complete integration is including the implementation of AR-BBS application.

\subsection{Deployment \& Configuration}

The system was implemented into a real prototype and integrated with software-based service for the end-user. The system testing was executed to test the whole system for the functionality and credibility of the system been developed. This section discusses the implementation, deployment and the results of the entire application.

\subsection{Interfaces}

The interface is a central part of android development application, where it depicts the flow of interfaces on an application. The main page allows an end-user to access the AR-BBS application. With the menu listed, it is allowed users to interact with the content by navigating and manipulating. By selection the content of AR-BBS, user can obtain information. Moreover, it provides other information as shown in Figure 4.1- 4.6. 
The International Journal of Multimedia \& Its Applications (IJMA) Vol.13, No. 6, December 2021

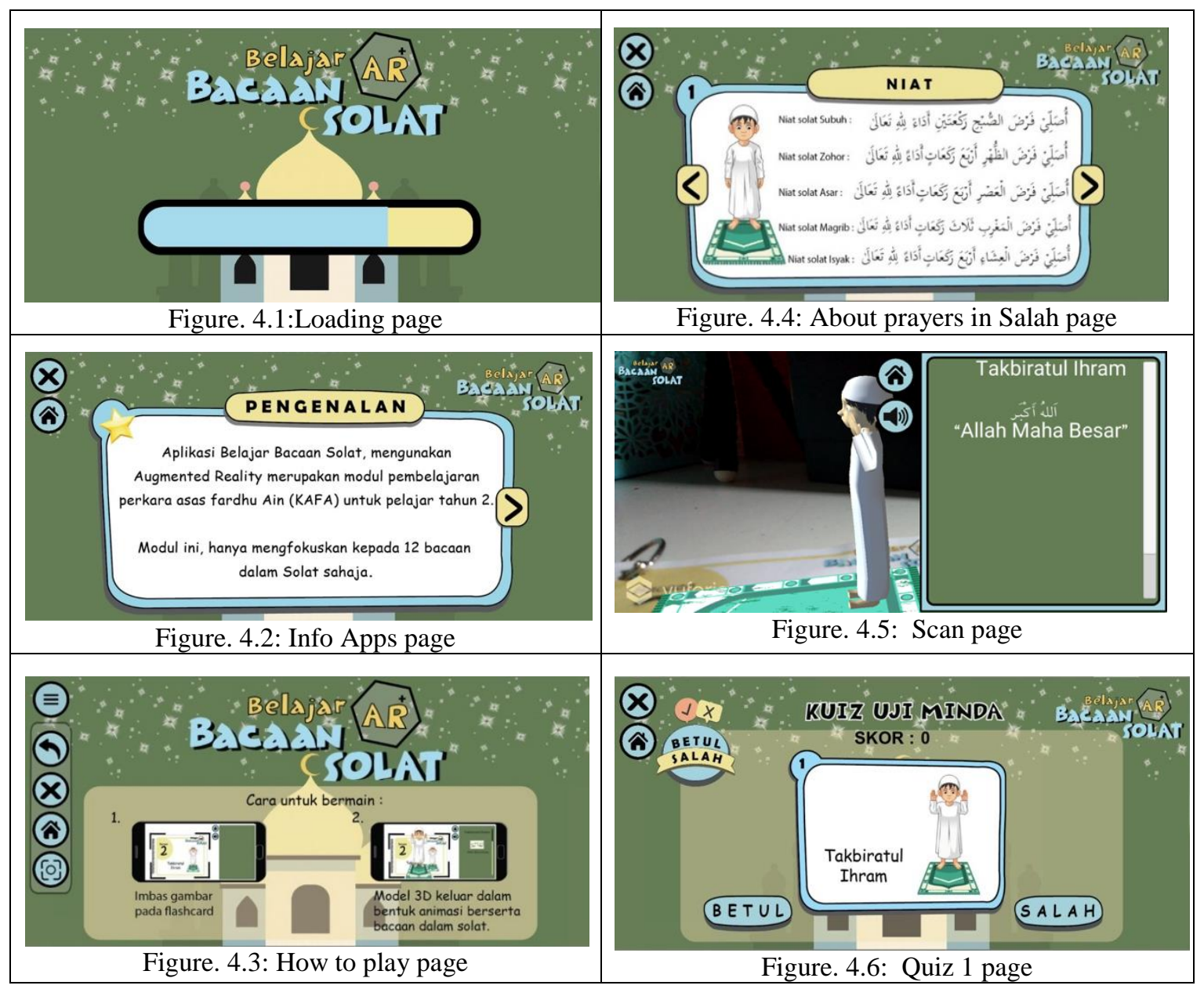

Image recognition is an imperative component of augmented reality systems. By use of identifying visual markers already embedded within the system, physical world objects are detected for superimposition of virtual elements. In order for an AR application to estimate the orientation and position of a camera with respect to the real-world frame, most applications employ a tracking technique known as marker based augmented reality.

Once you begin using the marker-based augmented reality system with a digital device, the image of the physical world captured by your camera is converted into a grayscale image to expedite the image processing algorithm. The algorithm then uses the image of the camera as well as the decoded marker ID to augment the virtual object onto the physical world model. By focusing the camera of whichever digital device, you are using to deploy the augmented reality app on the specified markers, the app is able to retrieve the information stored to display the threedimensional virtual object accurately. Besides that, Vuforia developer is a website that let developer check if the image is a suitable marker and every marker feature. Based on the following figure 4.7, it was illustrating the example of marker features. 
The International Journal of Multimedia \& Its Applications (IJMA) Vol.13, No. 6, December 2021
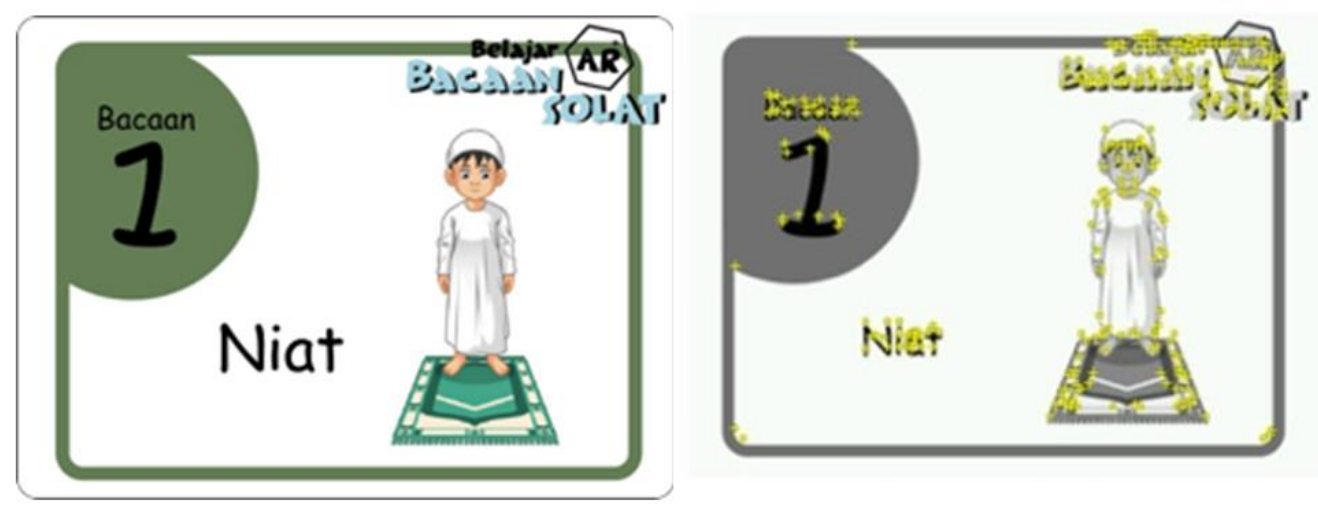

Figure. 4.7: Example of marker and feature

\subsection{Testing}

Product testing can be implemented in several ways in order to check if the users' requirements are met. In this paper, the testing was implemented to test the functionalities of the modules designed in the proposed framework. The testing called test case could be divided into Test Case 1 to Test Case 4. The test was conducted for the module main menu, how to play, AR scanner of 3D Modelling and KUIZ menu.

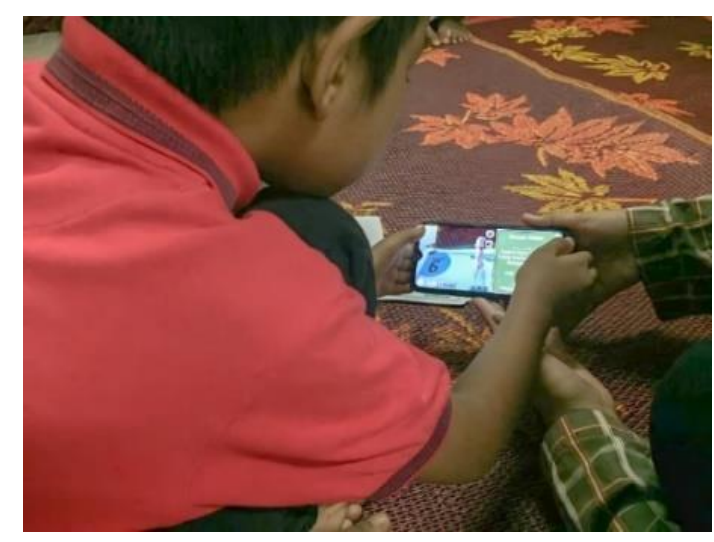

Figure 4.8: User testing 
The International Journal of Multimedia \& Its Applications (IJMA) Vol.13, No. 6, December 2021

Table 4.1: Test Case for Main Menu

\begin{tabular}{|l|l|l|l|}
\hline \multicolumn{5}{|c|}{$\begin{array}{c}\text { Test Case 1 } \\
\text { Test Case Name: Main menu } \\
\text { Application: AR-BBS }\end{array}$} \\
\hline Step & \multicolumn{1}{|c|}{ Procedures } & \multicolumn{1}{|c|}{ Expected Results } & Results \\
\hline 1 & $\begin{array}{l}\text { Click Hamburger button to get } \\
\text { listed sub menu }\end{array}$ & \multicolumn{1}{|c|}{ Listed sub menu } & Success \\
\hline 2 & Click a button of How to Play & Page How to Play appear & Success \\
\hline 3 & $\begin{array}{l}\text { Click a button of Info } \\
\text { Click KUIZ button to get } \\
\text { listed Quiz to play }\end{array}$ & $\begin{array}{l}\text { After click this button, user will } \\
\text { go to the page 'KUIZ' that have 2 } \\
\text { quiz to play. }\end{array}$ & Success \\
\hline 5 & $\begin{array}{l}\text { Click IMBAS button to get } \\
\text { scanner function for scan } \\
\text { flashcard }\end{array}$ & $\begin{array}{l}\text { After click this button, user will } \\
\text { go to the page 'IMBAS', user can } \\
\text { scan the flashcard at that page. }\end{array}$ & Success \\
\hline
\end{tabular}

Based on Table 4.1, users are able to access the application.

Table. 4.2: Test Case for How to Play

\begin{tabular}{|l|l|l|l|}
\hline \multicolumn{5}{|c|}{$\begin{array}{c}\text { Test Case 2 } \\
\text { Test Case Name: How to play } \\
\text { Application: AR-BBS Application }\end{array}$} \\
\hline Step & \multicolumn{1}{|c|}{ Procedures } & \multicolumn{1}{c|}{ Expected Results } & Results \\
\hline 1 & $\begin{array}{c}\text { Click Hamburger button to get } \\
\text { listed sub menu }\end{array}$ & \multicolumn{1}{c|}{ Listed sub menu } & Success \\
\hline 2 & Click a button of Exit & $\begin{array}{l}\text { After click this button, user will } \\
\text { exit from this this application. }\end{array}$ & Success \\
\hline 3 & Click a button of Home & $\begin{array}{l}\text { After click this button, user will } \\
\text { go to the page home again. }\end{array}$ & Success \\
\hline 4 & Click a scan button & $\begin{array}{l}\text { After user click this button, user } \\
\text { will go to the scan AR page. }\end{array}$ & Success \\
\hline
\end{tabular}

Based on Table 4.2, users get the explanation on how to use this application.

Table. 4.3:An AR scanner of 3D modelling

\begin{tabular}{|l|l|l|l|}
\hline \multicolumn{5}{|c|}{$\begin{array}{c}\text { Test Case 3 } \\
\text { Test Case Name: Scanner } \\
\text { Application: AR-BBS Application }\end{array}$} \\
\hline Step & \multicolumn{1}{|c|}{ Procedures } & \multicolumn{1}{c|}{ Expected Results } & Results \\
\hline 1 & $\begin{array}{l}\text { Scan a flashcard using } \\
\text { scan button }\end{array}$ & $\begin{array}{l}\text { Scanner recognised a card, then 3D } \\
\text { model and info were appeared }\end{array}$ & Success \\
\hline 2 & Click a button of Home & $\begin{array}{l}\text { After click this button, user will go } \\
\text { to the page home again. }\end{array}$ & Success \\
\hline 3 & Click a button of Sound & $\begin{array}{l}\text { After user click this button, user will } \\
\text { hear the prayer in Salah based on } \\
\text { flashcard that scan. }\end{array}$ & Success \\
\hline
\end{tabular}

Based on Table 4.3, users are able to scan a flashcard that show an animated 3D modelling. 
Table. 4.4: Test case for KUIZ menu.

\begin{tabular}{|l|l|l|l|}
\hline \multicolumn{4}{|c|}{$\begin{array}{c}\text { Test Case 4 } \\
\text { Test Case Name: Play a quiz } \\
\text { Application: "AR-BBS Application }\end{array}$} \\
\hline Step & \multicolumn{1}{|c|}{ Procedures } & \multicolumn{1}{|c|}{ Expected Results } & Results \\
\hline 1 & $\begin{array}{c}\text { Click KUIZ menu to go to "BETUL" or } \\
\text { "SALAH” button. }\end{array}$ & $\begin{array}{l}\text { After user click this button, user } \\
\text { will go to page quiz of 'BETUL } \\
\text { / SALAH', that have 6 } \\
\text { questions. }\end{array}$ & Success \\
\hline 2 & $\begin{array}{l}\text { Click KUIZ menu to go to "PILIHAN } \\
\text { JAWAPAN" button. }\end{array}$ & $\begin{array}{l}\text { After user click this button, user } \\
\text { will go to page quiz of } \\
\text { 'PILIHAN JAWAPAN' that } \\
\text { have 6 questions. }\end{array}$ & Success \\
\hline 3 & Click a button of Exit. & $\begin{array}{l}\text { After user click this button, user } \\
\text { will exit from this this } \\
\text { application and have to choose } \\
\text { "YA" or "TIDAK" to exit the } \\
\text { application. }\end{array}$ & Success \\
\hline
\end{tabular}

Based on Table 4.4, users are able to play a quiz module in the application.

\section{Conclusions}

AR-BBS application enhances students understanding and creates a more engaging and interactive learning that uses new era technology to help people, especially students and teachers as it was provided learning in the interesting way. Testing was implemented to check whether the users' requirements were met. In the future, this application is ready to be implemented in the real environment in order to test its usability and user experience. The target respondents are the standard primary school students as we designed the contents for this application. This research was achieved the objectives and scope of this research.

\section{ACKNOWLEDGEMENTS}

This project is partially funded by the Research Management, Innovation and Commercialization Center, Universiti Sultan Zainal Abidin.

\section{REFERENCES}

[1] K. Awang, S. N. W. Shamsuddin, I. Ismail, N. A. Rawi, and M. M. Amin, "The usability analysis of using augmented reality for linus students,” Indones. J. Electr. Eng. Comput. Sci., vol. 13, no. 1, pp. 58-64, 2019, doi: 10.11591/ijeecs.v13.i1.pp58-64.

[2] N. Saforrudin, H. B. Zaman, and A. Ahmad, "Pengajaran masa depan menggunakan teknologi Augmented Reality dalam pendidikan Bahasa Melayu: Tahap kesedaran guru," J. Pendidik. Bhs. Melayu, vol. 2, pp. 1-10, 2012, doi: 10.5539/ass.v9n11p1.

[3] N. I. M. M. Mahmud, I. Ismail, S. N. W. Shamsuddin, S. Safei, and M. A. M. Arsad, "Learning performance assessment using mobile-based augmented reality application for preschool environment," Int. J. Recent Technol. Eng., vol. 8, no. 2 Special Issue 3, pp. 436-439, 2019, doi: 10.35940/ijrte.B1076.0782S319.

[4] M. M. Amin, N. Rahim, S. Safei, and W. M. R. Wan Idris, "Utilization of automated virtual panoramic environment in online public accommodation booking system," J. Telecommun. Electron. Comput. Eng., vol. 9, no. 2-4, pp. 59-63, 2017. 
The International Journal of Multimedia \& Its Applications (IJMA) Vol.13, No. 6, December 2021

[5] S. Boonbrahm, P. Boonbrahm, and C. Kaewrat, "The Use of Marker-Based Augmented Reality in Space Measurement," Procedia Manuf., vol. 42, no. 2019, pp. 337-343, 2020, doi: 10.1016/j.promfg.2020.02.081.

[6] I. E. Sutherland, "Sketchpad : A Man-Machine Graphical Communication System , Unclassified," in Doctor, vol. 23, no. 296, 1963, pp. 329-346.

[7] Huttenlocher, Computer Science Handbook, Second Edition. 2004.

[8] H. E. Pence, "Smartphones, Smart Objects, and Augmented Reality," Ref. Libr., vol. 52, no. 1-2, pp. 136-145, 2010, doi: 10.1080/02763877.2011.528281.

[9] S. C. Yuen, E. Johnson, and E. Johnson, "Augmented Reality: An Overview and Five Directions for AR in Education Augmented Reality: An Overview and Five Directions," vol. 4, no. 1, 2011, doi: 10.18785/jetde.0401.10.

[10] Z. Zainuddin, U. Hasanuddin, I. S. Areni, and U. Hasanuddin, "Aplikasi Augmented Reality pada Sistem Informasi Smart Building,” no. February 2017, 2016, doi: 10.22146/jnteti.v5i3.258.

[11] Z. Nordin, "Penguasaan Bacaan Rukun Qauli Dalam Solat Dalam Kalangan Murid Tahun 4 Sekolah Rendah.," 2016.

[12] S. Ramzan, "Courseware on e-solat in mobile," 2010.

[13] A. M. Siti Zuraida et al., "Aplikasi Mudah Alih Panduan Solat dan Penggunaannya The User Guide of the Mobile Muslim Prayer Application," 'Ulum Islam., vol. 16, pp. 43-61, 2015, doi: $10.12816 / 0028491$.

[14] Hexa Setia, “AR Ajar Saya Solat.” 2018.

\section{AuTHORS}

Normala Rahim received the Diploma and Bachelor's degree in Photography and Creative Imaging from the Universiti Teknologi MARA (UiTM) in 2006 and 2008, respectively. She was awarded the Master's and Ph.D. degree in Information Technology from the Universiti Kebangsaan Malaysia in 2012 and 2020, respectively. She is currently a Senior Lecturer in Faculty of Informatics \& Computing, Sultan Zainal Abidin University (UniSZA) in Besut Campus under School of Multimedia Study. She also as the Coordinator of Educational Technology, Center for Management of Academic Excellence \& Innovation, Universiti Sultan Zainal Abidin. Her research interests include Human-Computer interaction that includes the multimedia application, user interaction design, usability \& user experience, virtual and augmented reality, and e-learning.

Wan Rizhan or his full name Wan Mohd Rizhan Wan Idris is currently a senior lecturer in Faculty of Informatics \& Computing, Sultan Zainal Abidin University (UniSZA) in Besut Campus under School of Multimedia Study. He received his Master of Science (Multimedia) and Ph.D in Creative Multimedia since 2010 and 2020. His main research areas focus on motion capture, motion recognition, virtual reality and $3 \mathrm{D}$ animation.

Ismahafezi Ismail is a Senior Lecturer at the Faculty of Informatics and Computing, Universiti Sultan Zainal Abidin (UniSZA), Malaysia. His research focuses on computer games, computer animation, virtual reality, and augmented reality.

Maizan Mat Amin obtained her Master of Science (Computer Science) majoring Multimedia in 2003 from Universiti Putra Malaysia, Bachelor of Information Technology (Information Science) in 1999 from Universiti Kebangsaan Malaysia (UKM), and Diploma of Information Technology from Kolej Agama Sultan Zainal Abidin (currently known as Universiti Sultan Zainal Abidin (UniSZA)). She joined Universiti Sultan Zainal Abidin (UniSZA), Terengganu, Malaysia since 1999 and one of the Senior Lecturer at School of Multimedia, Faculty of Informatics and Computing, UniSZA. Her research interests are in Multimedia, Human Computer Interaction, (1) Visual Informatics, Virtual and Augmented Reality, and e-Learning.
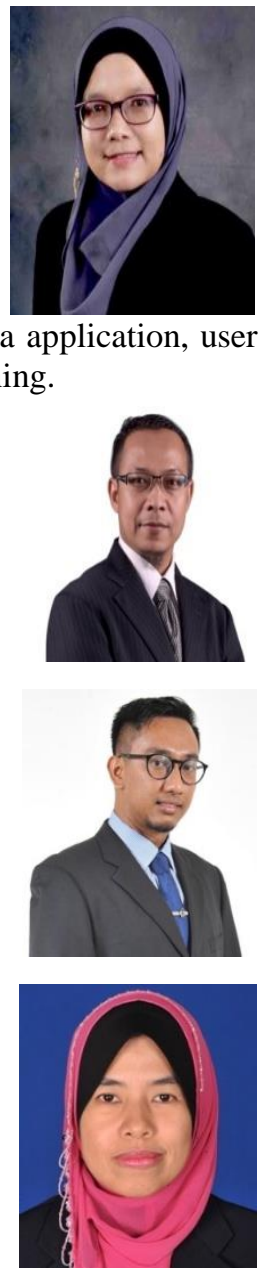
The International Journal of Multimedia \& Its Applications (IJMA) Vol.13, No. 6, December 2021

Wan Malini Wan Isa received the B.Sc. degree (Hons.) in computer science from Universiti Putra Malaysia (UPM), Malaysia, in 2006, and the M.Sc. degree in computer science from Universiti Putra Malaysia (UPM), Malaysia in 2008. In 2009, she joined Universiti Sultan Zainal Abidin (UniSZA), Malaysia, as a Lecturer. She was awarded Ph.D. degree in Information Technology from the Universiti Kebangsaan Malaysia in 2021. She has published more than 20 articles with a citation of 100 and H-index six (Google Scholar). Her research interests include multimedia application, knowledge base, serious games, human computer interaction and e-learning.

Nur Saadah Mohd Shapri is a Senior Lecturer in Faculty Informatic and Computing in Universiti Sultan Zainal Abidin (UniSZA). He holds a PhD in Computer Science (Industrial Computing) from National University of Malaysia (Universiti Kebangsaan Malaysia, UKM). His research area is in Computer Graphics and Simulation, Multimedia Computer Programming Games Design \& Development Visualization, Simulation Computer Graphics Application \& Techniques, Collision Detection between 3D and Deformable Models in Virtual Environment. He is a reviewer of more than 10 international journals and conference proceedings. He is also a member of the International Association of Engineers in Computer Science Society (IAENG) and ORACLE.

Rafhanah Binti Ramlan received the Diploma in information Technology on 2017 and Bachelor of Information Technology (Informatics Media) on 2021 from University Sultan Zainal Abidin (UniSZA).
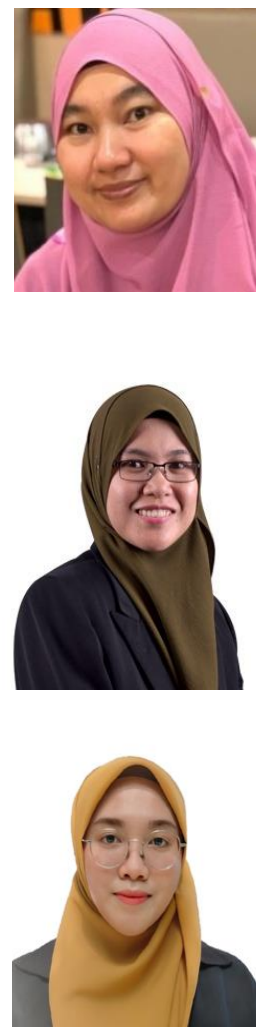